\title{
SOCIAL ECONOMIC PERSPECTIVES OF HOMECOMING TRADITION: INDONESIAN CONTEXT
}

\author{
Adrie Oktavio* \\ Agoes Tinus Lis Indrianto \\ Faculty of Tourism, Universitas Ciputra, Surabaya, Jawa Timur, 60219 Indonesia
}

\begin{abstract}
Homecoming has been practiced by most Indonesians as a routine tradition that cherished every year. This interesting practice has developed rapidly as an impact of the integration of capitalist economic systems in the early 1970s. The tradition of homecoming in Indonesia mostly occurs at the moment of religious holidays. This phenomenon is considered an essential part of the celebration. As the largest Moslem population in the world, the most prominent homecoming activity in Indonesia mostly happens during Eid Mubarak Celebration. At this moment, not only Moslem but almost all the people in the country go back to their hometown. Every year, this tradition is getting bigger in numbers and giving more significant impacts on the country in terms of social and economics. Therefore, this study tries to describe the homecoming tradition for Indonesia, specifically seen from a socio-economic perspective. As a qualitative content analysis study, this study analyses related works of literature, documentation, and publications relevant to the topic. The result is written descriptively by explaining the phenomena, discussing the impacts and proposing solutions. The results show that going home is proven to provide a substantial multiplier effect on the socio-economic side. From social perspectives, homecoming means the fulfillment of primordial and emotional interests to strengthen the relationship between family and friends. On the other hand, this tradition also boosts the economic development of the regions, which is interpreted as
\end{abstract}

\footnotetext{
*Corresponding author: adrie.oktavio@ ciputra.ac.id eISSN 2636-9265 (C) Centre for Civilisational Dialogue DOI: https://doi.org/10.22452/KATHA.vol15no1.3
} 
equalization or circulation of money from urban to rural areas in the country.

Keywords: homecoming, tradition; impacts, social and economics

\section{Introduction}

The phenomenon of coming home is not only happening in Indonesia but also experienced by many other countries. The homecoming tradition is usually triggered by religious momentum. For example, Egyptians usually gather with extended families on religious holidays Eid al-Adha (Egypt Independent, 2017). A large number of overseas Chinese travel to their hometown during Chinese New Year celebrations, also known as Imlek (Dou \& Miao, 2017). South Koreans also carry out the tradition of going home while celebrating Harvest Day or commonly called Chuseok. At this moment, most South Koreans will return home to visit their ancestors' altar (90 Day Korean, 2016). In India, large-scale population movements usually occur during the Light Festival or Deepavali celebrations, which are usually celebrated for 5 consecutive days (Balashanmugam, Nehrukumar, Ramanathan, \& Balasubramanian, 2014). A majority Muslim population in Bangladesh undergoes a tradition of going home during the Eid-ulFitr holidays (Hossain, 2010). In developed countries like the United States, the tradition of going home or returning home is also carried out by residents during Thanksgiving celebration (Siskind, 1992).

In Indonesia, going home has become an annual tradition (Yulianto, 2011). The term Mudik actually comes from the Javanese language, namely the acronym of the words Mulih and Dilik (Kompas, 2018), which later called Mudik. This word became popular term among the people of Indonesia. Besides going home, the term return home is also used by some people, especially those living on the Sumatra with Malay culture. The term kampung in the Acehnese language is called gampong, and in the Minang language is called kampuang.

The phenomenon of going home emerged and became an interesting trend since cities in Indonesia developed rapidly as the 
impact of the integration of the capitalist economic system in the early 1970s (Soemantri, 2007). Townspeople, most of whom are migrants, carry out homecoming activities on certain occasions, which are quite lengthy and have cultural and religious significance. The tradition of going home in Indonesia usually occurs at moments of religious holidays such as Eid al-Fitri, Eid al-Adha, Easter, and Christmas, where migrants spread out throughout the archipelago and even abroad return to their hometown to meet and visit their parents and relatives (Aly, 2005).

A moment when a large scale of the population movement in the homecoming tradition in Indonesia, which always receives much attention by many is the Eid holidays. In addition to being considered as an essential part of the most important religious holiday (the majority of Indonesian citizens are Muslim), homecoming tradition also causes considerable socio-economic impacts (Detiknews, 2012). Many stakeholders usually prepare themselves in advance to face the homecoming period. The government, for example, is usually busy preparing for repairs to infrastructure and fuel supplies, as well as maintaining the stability of prices of food staples. On the other hand, in the transportation business sector, both state and private, also began planning an adequate number of transportation fleets to anticipate a surge in passenger numbers.

In terms of quantity, the number of travelers from year to year has always increased. Based on data released by Indonesia Development and Islamic Studies (2018), the estimated number of travelers in the past five years has always increased. The estimated number of travelers in 2013 reached 30.8 million. In 2014, the estimated number of travelers increased by $1.9 \%$, reached 31.4 million. In 2015, the estimated number of travelers increased by $1.6 \%$ to 31.9 million. In 2016, there is an increase in the estimated number of travelers up to $1.3 \%$, around 32.3 million people, and in 2017 , the number of travelers was estimated at 33 million or an increase of $2.2 \%$ from the previous year. Seeing the large number of travelers above, one can imagine that at almost the same time, tens of millions of people make trips back and forth, either by land (using motorbike vehicles, cars, buses, and trains), by air (using airplanes), 
and by sea (using ships), which of course will have a separate impact on the homecoming activity.

The mudik phenomenon has been argued to raise several social and economic issues for the countries. Thus, the problem statement of this study is how mudik affected the Indonesian people's life in certain period? Therefore, this study aims to describe in particular how the tradition of going home in Indonesia from a socio-economic perspective may affect Indonesian people. It includes describing various kinds of problems that arise from the tradition of homecoming and solutions to answer existing problems. This study is significant to describe homecoming phenomena in Indonesia as part of social construction of Indonesian cultural identity. It brings insight and new perspectives of an activity that may affect the people who have diverse cultures in certain period.

\section{Literature Review}

The homecoming tradition describes the gap between urban and rural areas as the main impact of the high number of migrations from villages to big cities resulting in uncontrolled urbanization (Irianto, 2012). The phenomenon of tradition going back and forth emerged and became a trend since cities in Indonesia developed rapidly as an impact of integration in the capitalist economic system in the early 1970s (Soemantri, 2007). However, at the beginning of the $21^{\text {st }}$ century, the motive for homecoming has shifted towards a more rational direction. Residents who do not go home start to get a space of social tolerance. In rational explanations, they are understood that they might be busy with work, experience transportation problems, home security, etc. (Soemantri, 2007).

On the other hand, Soebyakto (2011) instead considers the tradition of homecoming as a consumptive trend even though on a small scale it can reduce poverty in the village such as the culture of zakat fitrah (alms-giving) payment during the Eid al-Fitr period which worth trillions of Rupiah. Based on hermeneutics, the mudik tradition can also be defined as the most profound expression of longing or symbol of spiritual awareness triggered by daily routines in the city, which encourages a person to return to his place of origin at a particular time (Majid, 2013). There is a study done by Herawati (2015) that reviewing the mudik tradition as the magnet of people, 
especially Javanese people to express their success while they are away from home. This moment is used to meet their family, friends, and relatives personally. An occasion to tell about their past life back home while directly and indirectly showcasing their achievements away from home.

\section{Methods}

The study is qualitative content analysis, using external resources to be identified, such as publications and observation of the phenomena. The aim of using content analysis is to organize and elicit meaning from the data collected in order to draw realistic conclusions from it. This study is using a large surface structure of content analysis by comprehensively review existing literature such as books, magazines, journals, and other publications both online and offline that are related to the topics raised in this study.

\section{Discussion}

\section{Historical Value and Culture of Mudik Traditions}

Semantic search shows that humans are identified by the place of origin. So it seems that the homecoming phenomenon implies a cultural heteronomy where there is an attraction between new situations and values with the old ones (Irianto, 2012). On the one hand, travelers cannot deny that they live, work, and live in the city, while, on the other hand travelers are very much bound by their origins, as stated by Huang, Ramshaw \& Norman (2016). From this, it appears that Indonesian society is very close to its past. So, it can also be interpreted that the phenomenon of homecoming is a symbol of the romance of life. The hometown is "home" to start when departing and going home, like a heritage that is always recorded in the mind and heart even though someone has traveled to distant places. Because in that hometown, some people feel they have been taught about the values of good character and sincerity (Yudono, 2015). The hometown can remind someone of the nature of himself about life. It is essentially a life that is not merely seeking money for livelihood, but life that is useful for others, especially for parents, 
families, and those around them. In Japanese context, a study done by Perez (2016) reveals the fact of returning home is a part of making of cultural Identity and its readjustment in life.

\section{Relationship between Homecoming and the Socio-Economic Field}

The tradition of homecoming in Indonesia has also become a phenomenon. Homecoming (Mudik) seems to be the peak of Indonesian rituals. The result of the struggle in the city and then spilled in his hometown when going home (Li, 2019). The villagers seemed to see that someone who had returned from wandering in the city was a successful profile, had a presentable appearance, and of course brought large sums of money even though many of them were working as factory workers and construction workers (Aulawi, 2017).

Mudik is proven to be able to provide an enormous multiplier effect from the social and economic side. As a social event, going home means fulfilling primordial and emotional interests to strengthen friendship relations (Zhao, Chen \& Xu, 2019). In Indonesian society, the tradition of going home, especially during Eid al-Fitr is a primary or highest social event and involves a great deal of human interaction because the majority of Indonesia's population is Muslim. Quantitative magnitude in this homecoming event makes Mudik tradition result in the most significant social problems, considering that large-scale community mobilization only occurs during the Idul Fitri homecoming (Herawati, 2015). As an economic event, Mudik is the highest economic event every year, because the homecoming event can provide economic equality throughout Indonesia. It has moved the wheel of the economy more quickly which means as equalization or circulation of money piled up in the city to areas or villages.

For the village community, Mudik tradition can also be a quite severe social problem, which is feared to damage the popular village culture and cooperation. The lifestyle brought by travelers from the city often hurts the pattern of behavior of rural communities. Many travelers when returning home often show their existence in physical forms such as property and money ownership as if it were the result of their success working in the city. Showing 
off the success often leads to the desire of the other family members or neighbors in the village to work in the city as a bridge to change their destiny, which eventually led to large-scale urbanization. Thus, inequality between villages and cities will always occur every year, whether in wealth or education level. As stated by study done by Gill (2019), the returning of educated persons from studying elsewhere may affect their quality of life back home.

\section{Social Meaning of the Mudik Tradition}

In Indonesia, the mudik tradition relates closely to urbanization, namely the movement or mobilization of the population (migration) from village to city (Yulianto, 2011). However, in most cases, in principle a person who has migrated to the city does not want to leave the traditions and cultural identity of the village that was left behind (Park, 2018). Village traditions and identities that are rarely found in urban life are those that blend with the surrounding environment. For example children who in their childhood lived in the village were used to using nature as a place to play with their friends. Such conditions are rarely found in urban life that tends to be more individualistic (El Din, Shalaby, Farouh, \& Elariane, 2013). In the end, Mudik is used by urban people as momentum to reminisce about his childhood in the village with his parents and relatives in addition to carrying out the pilgrimage to his parents or family members who have died. Often during the homecoming, school reunions were held with teachers and friends when they were educated in the village (Fuad, 2011).

According to Rinakit (2013), Mudik is also often used as a medium of socialization for urban communities to families, friends, and neighbors about the various possibilities for working in cities based on their own experiences. So that after going home, there is usually mobilization of rural communities, especially those who do not have agricultural land, to try their luck in the city even though the expected work is not following reality and not a few that invite risk. Borrowing the term functional sociologist, the tradition of homecoming contains a hidden goal in the form of propaganda that life in the city is more assured of its welfare and easier to obtain money than living in the village (Affandy, 2011). However, as stated 
in Garz (2015), the homecoming is also a chance to have multicultural friends and family.

In the process of social interaction, primordial nuances of the village were also carried away and colored the lives of urbanites (Mohan, 2010). For example, in several major cities in Indonesia, there are several villages such as Kampung Bugis, Kampung Jawa, Kampung Bali, Kampung Melayu, Kampung Madura, Kampung Dayak, and more. Hidayat (2013) explained that the stronger the tradition of mudik in Indonesia was estimated because of the feeling of togetherness and solid attachment within the community structure itself, both the horizontal community attachment and the attachment between individuals and their hometowns. This kind of attachment in a sociological perspective is called total attachment, which refers to a situation where a person releases his ego in himself and is replaced by a sense of togetherness. This sense of togetherness then encourages a person to always adhere to the values and norms that develop in society.

\section{Economic Value in Mudik Traditions}

Public activity before going home brings consequences to increasing economic activity in urban areas. Towards the time of mudik, urban communities are usually competing to meet their cosmic needs such as buying new clothes, purchasing tickets for transportation services (planes, ships, trains, and buses) and fulfilling other secondary needs (Mardiah, 2017). Indonesian society is already known as a consumptive society (Zaman, 2017). When the items owned are still functioning, but when there is a promotion of a new product, there is a tendency to buy the new one. The basis is to keep up with the latest developments or trends and have the financial strength to buy them without considering their essential functions. The tendency of consumptive behavior is also carried out by people whose financial strength is inadequate. Even to get the latest products, they get into debt. These characteristics clearly illustrate how consumptive Indonesian society is (Solihin, 2015). With these characteristics, it is straightforward for manufacturers to offer the latest products ranging from vehicles, household appliances, clothing, and electronic products. Coupled with the lure of discounts and the momentum of religious holidays such as Eid al-Fitr and Christmas 
are strong drivers for consumptive behavior. Through intensive advertising, moments like Eid and Christmas are identified with ownership and use of new products.

Consumptive communities no longer think about prices because they think that the goods to be purchased have got a discount (Wati \& Suryanto, 2016). The need for homecoming with new goods makes people inattentive and becomes more consumptive (Mujiran, 2016). This pattern of thinking is embedded in the Indonesian people and passes down from generation to generation until to date. Moreover, the pattern of social comparison of the community is also relatively high. For example, when a neighbor buys new items for celebrating Eid al-Fitri, trigger other neighbors to buy new items. During homecoming, travelers bring vehicles to be shown to the neighbor and bring new items as souvenirs. It is used as a measure of the success of working or traveling in the city, so it is a necessity to bring or use new things when going home (Rosita, 2016).

For this "mass social ritual," urban society often ignores long-term aspects of financial management. The homecoming destination is often set as an effort to "sow the results" of work that has been done for a full year in the city so that the culture of frugality is not valid as long as urban communities are in their hometowns. According to Dharmawan (2011) the tradition of "sprinkling the work of a year" in the hometown during mudik is similar to millions of salmon, which naturally swim upstream once a year because they want to lay eggs and regenerate their offspring so that eco-biological sustainability occurs.

During Mudik period, business activities flourished in various sectors such as transportation, trade, tourism, culinary, and retail. The transaction value generated by these sectors during the period of homecoming can reach tens of trillions of Rupiah. Businesses are competing to offer products and services to hunt for blessings from homecoming activities because the benefits can be multiplied. Businesses can at least reap 30 percent more profit during this period than other time of the year. The benefits obtained can be categorized into two, namely, direct benefits and indirect benefits. Direct profits are obtained by the increase in business turnover and profits during mudik moments when transactions jump 
sharply than ordinary days. Meanwhile, business people can reap the indirect benefits of the mudik by improving its customer relations and brand image in the media campaigns. As part of boosting a company image, some big companies perform their CSR (Cooperate Social Responsibility) activities during this period. As studied by Ningtyas (2017), the free bus ride for mudik is often offered by some companies to get public exposure and increase its company brand image.

Some facts of business opportunities over the phenomenon of mudik that can generate direct profits in the form of increased turnover and profits include the surge in the number of passengers in land transportation (bus, travel, train), sea, and air transportation to get them home and return to their domicile during the week before and after the Eid. The addition of $14 \%$ fuel supply to anticipate the need for transportation during that period by PERTAMINA (Indonesian state-owned oil and natural gas corporation) is followed by an increase in turnover. The profit of car or motor-cycle repair shop increases by 2-3 folds because the request of checking and tuning up the vehicles to be used for Mudik soars dramatically. Vehicle rental services also enjoy the surge. The turnover of traders along the homecoming route also increases. Their operating hours are extended up to 24 hours during the homecoming and backflows. Some examples of activities carried out by many companies that indirectly benefit from homecoming moments to improve customer relations are a media campaign and the company's brand image. Beberapa contoh kegiatan lainnya yang banyak dilakukan oleh perusahaan-perusahaan di Indonesia dalam memanfaatkan momen mudik adalah melakukan promosi besar-besaran melalui media offline ataupun online secara besar-besaran untuk meningkatkan meningkatkan citra perusahaan di mata pelanggan sekaligus mempererat hubungan dengan pelanggan.

\section{The Impact of Mudik Tradition on Urbanization}

Many people expect rural economic development to increase along with the phenomenon of "economic succession of life" as happened in the tradition of Mudik, but the reality says the opposite. The city remains a magnet for many villagers who complain about their fate and then leave their villages. Economic activities concentrated in 
urban areas encourage rural people to migrate. There is a high gap between cities and rural areas. According to Alkhudri (2011), as long as there are inequalities between cities and rural areas, the phenomenon of urbanization cannot be prevented. The high rate of this migration is a result of the industrialization strategy by the government which creates faster urban growth, thus generating new problems as well as the development imbalances in the countryside. Related to this, BAPPENAS (the National Development Planning Agency) stated that currently 56 percent of Indonesia's population is still living in rural areas, while 44 percent are in urban areas. In 2015, 56 percent of the population lived in urban areas. The remaining 44 percent live in rural areas. Mudrajat in Tarmidji (2011), states that faster urban growth will result in the migration to major cities that are premature. It means that migration from rural to urban areas occurs before the industry in the city is established. The newcomers in the city who do not get a job will try to make their fortune by participating in economic activities in informal sector, which are self-employment. Additionally, the phenomenon of Mudik also affects community activities in various regions, locations or places. The problems that have arisen in various locations as the impact of homecoming is the increase of road accidents due to negligence of travelers. People are usually disregarding safety during the flow of homecoming activities. Some of them who use motorcycle to go to their hometowns are seen without a helmet, particularly the children. A study conducted by Adisthi, Meisclin \& Tjahono (2017) revealed several aspects causing the road incidents during the mudik. It revealed that human error is the dominant factor that causing the accidents on the road during mudik.

Mobilization people after the homecoming from the village back to the city has a bad impact on the increase in urban population compared to before. As a result, it was common for residents who return home to their villages take with them their relatives to settle in the city after the homecoming. They do this to try their luck, or something else encourages them to settle in the city (Amery, 2019). It happened because the migrants who returned to their hometown often brought large amounts of money and lots of souvenirs. The people in the hometown perceive this as a success. Whereas in fact, 
only handful of migrants are successful. Only few migrants are actually grabbed employment opportunities in the city. Residents at home feel pressured to follow their success. This condition more or less affect the increasing population on the destination (city) as well as the city's carrying capacity.

\section{The Impact of Mudik Tradition in Indonesia}

The positive aspects of the mudik lebaran tradition, namely the spirit of kinship, and mutual forgiveness can be used as social capital to overcome the crisis of trust that is a problem of this nation. The crisis of trust faced by this nation has been so acute, not just a crisis of trust from overseas but also a crisis of internal trust between the people and the government, political elites, and religious leaders. Because of the importance of the trust element as a fundamental component of a democratic government, the momentum of this annual Eid will be more meaningful and not merely a ritual when all elements of society are aware of the importance of family spirit, which is at the core of this Mudik tradition. The family spirit must be built from the smallest scope, namely the family itself, the community and then to the broader scope, the state.

Although the tradition of lebaran homecoming has had a positive impact to stronger family solidarity, this tradition also hurts the city and the village. For the city, the tradition of Mudik is the beginning of the problem of urban development, because in general, the number of people coming along with those who return to hometown after the homecoming is greater than the number of people who perform the homecoming itself, Zhang, Huang, Green \& Qiu (2018). The resulted increase in population in the city will cause both physical and social problems, such as environmental degradation, the development of slums, housing needs, transportation problems, traffic congestion as well as unemployment, street children, homeless people, beggars, juvenile delinquency and even on Commercial Sex Workers (CSWs).

\section{Mudik Problems in Indonesia}

The phenomenon of Mudik is not only seen as a social phenomenon that illustrates the existence of a massive community mobilization 
back to hometowns with all of relevant activities before a specific day in the year, but also myriads of problems that come afterward. Demographically, the phenomenon of homecoming will greatly affect community activities in various regions, locations, or places.

The problem posed in various locations which are the centers for the flow of homecoming is the increasing number of accidents due to negligence of travelers who do not consider their safety during the travel, namely wearing no helmet, especially in children. During the trip, it is common for travelers to be robbed, drugged, and pickpocketed. The criminal acts that occurred not only occurred on the travelers' journey but also increased in certain areas, where the location of urban communities are overcrowded during the homecoming time, and travelers left their houses empty to return home. During these times the homes left for homecoming were often looted by robbers.

According to Manurung (2013), the problems of annual mudik tradition in Indonesia are similar in nature. These problems, for instance, is the lack or absence of facilities and infrastructures large and massive enough to accommodate the tidal of people traveling at the same time. The problem of homecoming in Indonesia is dominated by transportation problems.

In Kompasiana (2014), the problems related to land transportation are as follows:

a) The carrying capacity of vehicles, related to neglected capacities such as density and the number of passengers that is not proportional to the amount of transportation readiness.

b) Damage and maintenance of the north coast road of Java and the Sumatra route which are always problematic and damaged every year. And the issue of travelers who use motorbikes until now has no solution and is one of the factors in the high rate of accidents and fatalities before Eid.

c) The government has also not fully utilize alternate routes. The Mudik routes for vehicles so far, are still focused on the main route. So, that road repairs, including alternative lane infrastructure, missed the government's attention.

d) Some roads and bridges in the regions are not operable or available for use because it is still being built, repaired or 
finished during homecoming. It should have been completed before the mudik period begins.

e) Weak management and enforcement on the ticket pricing during Mudik period have caused tickets brokerage practice to go rampant and troubles people prior to Eid al-Fitr. Every year tickets are sold out because ticket brokers bought them early. As a result some people are forced to buy from the brokers at an extra price.

\section{The Solution to Mudik Problems in Indonesia}

According to Syahnakri (2011) in Kompas, mudik is a problem that must be approached with a strategic (long-term), comprehensive, and integrated concept. Therefore, the president, by policies must take actual hands-on control (in military terms it is referred to as a command). The government must take strategic policies and its implementation should not be delayed, they are: first, the construction of mass transportation facilities and infrastructure such as the making of double tracks between Cikampek and Surabaya as well as improving the quality of carriages, as well as the addition of sea transportation facilities which has never done since the end of Orde Baru (designation for the reign of President Soeharto in Indonesia). This construction or procurement must be subsidized by the government. In addition to being an obligation and responsibility of the government, this is also impossible for PELNI (Indonesian Shipping Company) and PT KAI (Indonesian Railways Company) because it is outside its capacity, even though the construction of these facilities/infrastructure is urgent and immediate.

Second, the development of new economic centers in eastern Indonesia. Rapid economic growth outside Java would attract the interest of the Javanese population so that there would be spontaneous immigration, which would reduce the population density on Java. The largest number of travelers coming from Jakarta, Bogor, Tangerang, and Bekasi areas and the number of traffic accidents and their casualties mostly occurred in Java. Therefore, reducing density becomes very urgent. Third, the most important is the traffic discipline enforcement campaign.

According to Wijaya (2013), the solution that must be enforced immediately is to improve public transportation 
infrastructure before homecoming and holidays to avoid excessive traffic accidents, especially for travelers who use motorbikes. As stated by Kholid (2018), the factors of tiredness are the most significant issues faced by Indonesian people during mudik. Therefore, there should a systematic approach to handle this matter to reduce the number of people getting tired on the road. Then, in addition to infrastructure development, macro solutions that are not less important are decentralization and population distribution.

\section{Conclusion}

The essence of homecoming or so-called mudik is that people who live in the cities return to their villages. Mudik is a regular and annual social phenomenon. It is understood as a mass vacation of large city residents leaving for their hometown (smaller villages or cities). In homecoming, there will be a process of social contact (social contact). Those who come home usually want to build connections and ask for forgiveness from their loved and close ones: neighbors, family, and friends in their hometown.

There are three essential meanings contained in the mudik lebaran tradition, namely religious, social and economic events. As a social event, it means fulfilling primordial and emotional interests to strengthen friendly relations. As an economic event, Mudik is the highest economic event every year, because it can provide economic equality throughout Indonesia.

\section{References}

90 Day Korean. (2016). Chuseok in Korea (Korean Thanksgiving). Retrieved September 2, 2018, from https://www.90daykorean.com/chuseok-in-korea/

Adisthi, M. Meisclin, V.N, Tjahono, T. (2017). Evaluasi Kecelakaan Lalu Lintas Selama Mudik Lebaran Melalui Jalur Darat di Indonesia tahun 2015 dan 2016. Jurnal Transportation, Vo17, No.1. 
Affandy, S. (2011). Nilai Sosial Ekonomi Tradisi Mudik. Retrieved September 4, 2018, from https://news.detik.com/opini/1711569/nilai-sosial-ekonomitradisi-mudik

Alkhudri, A. T. (2011). Komunalitas terbayang: Mudik sebagai fenomena kultural-kependudukan. Sosialita, 9(1), 50-59.

Aly, A. (2005). Tradisi lebaran dan praktik hidup multikultural. Kalimatun Sawa, 03(01), 1-48.

Amery, R. (2019) The homecoming of an Indigenous Australian diaspora as impetus for language revival: the Kaurna of the Adelaide plains, South Australia. Current Issues in Language Planning, 20:1, 81-99.

Aulawi, A. (2017). Inilah Perbedaan Perantau yang Benar-benar Sukses dan yang Sok Sukses, Saat Mudik Pulang Kampung. Retrieved September 4, 2018, from https://www.inovasee.com/perbedaan-perantau-sukses-dansok-sukses-saat-mudik-lebaran-23210/

Balashanmugam, P., Nehrukumar, V., Ramanathan, A. R., \& Balasubramanian, G. (2014). A study on the influence of Deepavali festival on noise level in Chidambaram town, Tamilnadu, India. International Journal of Current Engineering and Technology, 4(1), 300-304. Retrieved from https://pdfs.semanticscholar.org/e122/cfef6f4620dd0e544f1 9f7ce3b615459ecd0.pdf

Detiknews. (2012). Budaya Mudik dan Dampak Positifnya. Retrieved September 2, 2018, from https://news.detik.com/kolom/d-1992133/budaya-mudikdan-dampak-positifnya

Dharmawan, B. (2011). Homecoming a.k.a. mudik. Retrieved September 7, 2018, from https://budinddharmawan.wordpress.com/2011/08/28/home coming-a-k-a-mudik/ 
Dou, J., \& Miao, S. (2017). Impact of mass human migration during Chinese New Year on Beijing urban heat island. International Journal of Climatology, 37(11), 4199-4210.

Egypt Independent. (2017). In pictures: Muslims celebrate Eid alAdha festival. Retrieved September 2, 2018, from https://www.egyptindependent.com/pictures-muslimscelebrate-eid-al-adha-festival/

El Din, H. S., Shalaby, A., Farouh, H. E., \& Elariane, S. A. (2013). Principles of urban quality of life for a neighborhood. $H B R C$ Journal, 9(1), 86-92.

Fuad, M. (2011). Makna hidup di balik tradisi mudik lebaran: Studi fenomenologi atas pengalaman pemudik dalam merayakan Idul Fitri di kampung halaman). Komunika, 5(1), 107-123.

Garz, D.(2015). Going Away. Going Home! Coming Home? The Migration of Korean Nurses and Miners to Germany and Their Return in Retirement to Korea's German Village Together with Their German Husbands. The Journal of Multicultural Society. Vol. 6, No. 1, pp. 161-183.

Gill, S. (2019). The Homecoming An Investigation into the Effect of Studying Overseas on the Returned Chinese Postgraduates' Life and Work in China. Spotlight on China. University of Calgary, Canada.

Herawati. (2015). Lebaran Menjadi Magnet Untuk Mudik Bagi Masyarakat Jawa. Magistra, no 93.

Hidayat, R. (2013). Esensi Mudik. Retrieved September 3, 2018, from https://www.republika.co.id/berita/jurnalismewarga/wacana/13/07/30/mqqgap-esensi-mudik

Hossain, M. M. (2010). The emerging consumer culture in Bangladesh: Everyday life and festivals in rural areas. Journal of Social Sciences, 6(3), 488-497. 
Huang, W.J., Ramshaw, G \& Norman, W.C (2016) Homecoming or tourism? Diaspora tourism experience of second-generation immigrants, Tourism Geographies. 18:1, 59-79.

Indonesia Development and Islamic Studies. (2017). Evaluasi Ekonomi Mudik 2017. Retrieved September 2, 2018, from https://ideas.or.id/2017/07/24/evaluasi-ekonomi-mudik$2017 /$.

Irianto, A. M. (2012). Mudik dan Keretakan Budaya. Humanika, 15(9). https://doi.org/10.14710/humanika.15.9.

Kompas. (2018). Dari Mana Asal Kata "Mudik" dan "Lebaran." Retrieved September 2, 2018, from https://nasional.kompas.com/read/2018/05/24/03300051/da ri-mana-asal-kata-mudik-dan-lebaran-

Kholid, A. (2018). Kajian Faktor-Faktor yang Berhubungan dengan Kelelahan Pengemudi Saat Mudik. Indonesian Journal of Nursing Research. Vol 1, No.1.

Li, M.(2019). Staging a social drama: Ritualized framing of the spring festival homecoming in Chinese state media. Journalism. Sage Journals. Vol 19, Issue 9-10, 2018

Majid, A. (2013). Mudik lebaran. Retrieved from http://file.upi.edu/Direktori/FPIPS/M_K_D_U/1959022519 85031-ABD_MAJID/ARTIKEL/TEOLOGI_MUDIK.pdf

Mardiah, A. (2017). Analisis perilaku konsumtif masyarakat muslim menjelang Idul Fitri di Kota Pekanbaru. Jurnal AlIqtishad, 13(II), 93-103.

Mohan, A. (2010). The country and the village: Representations of the rural in twentieth-century South Asian literature. University of Toronto. Retrieved from https://tspace.library.utoronto.ca/bitstream/1807/32945/1/M ohan_Anupama_201006_PhD_thesis.pdf 
Mujiran, P. (2016). Mudik, Tradisi dan Konsumerisme. Retrieved September 5, 2018, from https://indonesiana.tempo.co/read/81422/2016/07/15/mujira npaulus/mudik-tradisi-dan-konsumerisme

Ningtyas, D.E. (2017). Hubungan Program CSR (Corporate Social Responsibility) Mudik Lebaran Gratis terhadap Citra Perusahaan PT. Industri Jamu dan Farmasi Sido Muncul Tbk. Communicare : Journal of Communication Studies . Vol 4 No 2

Park, K. (2018). Kisah Sukses: Stories of Indonesian Migrant Worker Returnees Living in Greater Jakarta. The University of British Columbia.

Perez, M. (2016). Kikokushijo and Coming Home: The Relevance of Age in the Making of Cultural Identity and its Effect on the Readjustment Phase of Japanese Returnees. Humanities Review. Vol. 21

Rinakit, S. (2013). Analisis Politik: Mudik Lebaran. Retrieved September 7, 2018, from https://nasional.kompas.com/read/2013/08/07/0949392/Ana lisis.Politik.Mudik Lebaran.

Rosita, D. (2016). Mudik (antara) Silaturahmi dan Ajang Pamer. Retrieved September 5, 2018, from https://www.kompasiana.com/minnie/5782390d327b61330 896216b/mudik-antara-silaturahmi-dan-ajang-pamer.

Siskind, J. (1992). The invention of Thanksgiving: A ritual of American nationality. Critique of Anthropology, 12(2), 167191.

Soebyakto, B. B. (2011). Mudik lebaran: Studi kualitatif. Jurnal Ekonomi Pembangunan, 9(2), 61-67. 
Soemantri, G. R. (2007). Kajian sosiologis fenomena mudik. Jakarta. Retrieved from http://staff.ui.ac.id/system/files/users/gumilar.r09/publicatio n/kompilasi-buku.pdf

Solihin. (2015). Terpaan iklan mendorong gaya hidup konsumtif masyarakat urban. Jurnal Ilmu Politik Dan Komunikasi, $V(2), 41-50$.

Wati, M. Y., \& Suryanto, T. (2016). Faktor yang mendorong perilaku konsumtif siswa SMA di Surabaya (Studi deskriptif di pusat perbelanjaan Darmo Trade Center Surabaya). Kajian Moral Dan Pendidikan, 1(4), 107-121.

Yudono, J. (2015). Ritual Agung Bernama Pulang Kampung Kompas. Retrieved September 2, 2018, from https://nasional.kompas.com/read/2015/07/13/12201051/Ri tual.Agung.Bernama.Pulang.Kampung

Yulianto, V. I. (2011). Is the past another country? A case study of rural-urban affinity on mudik Lebaran in Central Java. Journal of Indonesian Social Sciences and Humanities, 4(01), 49-66. Retrieved from http://www.kitlvjournals.nl/index.php/jissh/index

Zaman, S. (2017). Pola konsumtif masyarakat urban dalam perspektif semiotik dan budaya. Paradigma Jurnal Kajian Budaya, 7(1), 40-49.

Zhang, H., Huang, Z. Y., Green, C \& Qiu, S. (2018) Place attachment and attendees' experiences of homecoming event. Journal of Sport \& Tourism. 22:3, 227-246.

Zhao, Y, Chen, F \& Xu. H. (2019) "It is a way of life": detecting Chinese students' wellbeing during the Spring Festival homecoming, Journal of Travel \& Tourism Marketing. 